ment by a multiplicity of individual suits, this might well be achieved by the damage requirement; few, if any, individual plaintiffs could show damage, while a proper class could be presumed to have sustained damage.

In any event, the damage requirement will not be abandoned completely in the unlicensed practice field. As long as courts confine to competitors the right to enjoin unlicensed practice, some sort of damage requirement is operating; competitors are more likely to have suffered damage than other plaintiffs. But, if plaintiffs are regarded as public protectors only, the rationale for a limitation to competitors of the right to enjoin is unclear. If individual suits are to be allowed, there would seem to be no reason why individual non-competitor plaintiffs could not protect the public as well as competitors. However, to allow non-competitors to sue would require complete abandonment of the damage requirement-a step which courts may well be unwilling to take. Nor would it seem necessary to take this step in order to achieve adequate public protection; the motivation for a non-competitor to sue will seldom arise.

\title{
STATE STATUTES: CONSTITUTIONAL SUBJECT-TITLE AND AMENDATORY REQUIREMENTS
}

No act hereafter passed shall embrace more than one subject, and that shall be expressed in the title ... and no law shall be revived or amended by reference to its title only, but the law revived, or the section amended, shall be inserted at length in the new act. 1

This and similar constitutional provisions have been used with increasing frequency but with diminishing success in attacking the validity of legislation. Since, as Justice Frankfurter has remarked, "today cases not resting on statutes are reduced almost to zero," ${ }^{22}$ such provisions are important tools for the lawyer who must deal with legislation. This comment will survey the Illinois decisions in order to appraise the likelihood of successfully attacking statutes by means of such a constitutional provision.

\section{SUBJECT-TITLE PROVISION}

The adoption of a constitutional requirement limiting each act to a single "subject" which must be described in the title resulted from dissatisfaction with the early English and American practice of enacting statutes without titles. $^{3}$ The generally expressed purposes of such a provision are several:

${ }^{1}$ IIl. Const. Art. IV, $§ 13$. Similar provisions appear in the constitutions of other states. E.g., Cal. Const. Art. IV, \$24; Ind. Const. Art. 4, \$19; Fla. Const. Art. III, \$16; Md. Const. Art. III, \$29.

${ }^{2}$ Frankfurter, Some Reflections on the Reading of Statutes, 47 Col. L. Rev. 527 (1947).

${ }^{3}$ The titles to early statutes were supplied by a clerk after enactment, indicating his understanding rather than that of the legislature. Where titles were supplied by the 
to prevent legislative "log-rolling"; 4 to prevent surprise on the legislature by crafty insertion of provisions, not related to the title, which might not be enacted if the provisions were properly indicated by the titles; and to notify the public, through accurate labeling of the proposed legislation, so that they may be heard thereon. ${ }^{5}$

Accuracy of Title. With the growing volume of legislation at each session, and the pressure tactics of lobbyists which often meet little or no opposition, the legislator is clearly dependent upon accurate labeling of statutory contents. And the interested layman who is presumed to know the law should be given every reasonable opportunity to know that the statute exists. On the other hand, the courts ought not and will not allow such procedural requirements to frustrate legitimate and beneficial legislation merely because a better title might have been used. ${ }^{6}$ Formulation of the test to be used has been difficult, and its application has led to questionable results.

A fair test has been to inquire whether a reasonable reader or an "ordinary person of intelligence" would be misled as to the general purport of the statute. ${ }^{7}$ If a layman would not be misled, it is unlikely that a legislator, lawyer, or other experienced person could be confused. Occasionally, however, in determining whether a questioned provision is within the subject expressed in the title, the court has enunciated a second test. If the provision is such that "if traced back [it] will lead the mind to the subject as the generic head," the constitutional requirement is met. ${ }^{8}$ This second test, which in effect requires a reading of the provision in question, would appear to place such a burden on the reader as to defeat the protection intended by the constitution.

In any event, recent decisions have clearly adopted a liberal attitude in favor of upholding statutes attacked on the ground of inaccuracy of title. The typical statement is:

legislature, they were generally affixed after enactment and with little attention from the members. I Cooley, Constitutional Limitations 291-2 (8th ed., 1927); Sutherland, Statutory Construction $\$ 1701$ (3d ed., 1943).

"This has been defined as "[t]he practice of bringing together into one bill subjects diverse in their nature, and having no necessary connection, with a view to combine in their favor the advocates of all, and thus secure the passage of several measures, no one of which could succeed upon its own merits." People v. Mahaney, 13 Mich. 481, 494 (1865). It has been commented that log-rolling is still possible though perhaps more difficult. Manson, The Drafting of Statute Titles, 10 Ind. L. J. 155, 156 (1934).

${ }^{5}$ E.g., see People v. Gebbie, 5 III. 2d 565, 126 N.E.2d 657 (1955) ; People v. Mahumed, 381 IIl. 81, 44 N.E.2d 911 (1942); Galpin v. City of Chicago, 269 Ill. 27, 109 N.E. 713 (1915).

- See Baim v. Fleck, 406 III. 193, 92 N.E.2d 770 (1950).

${ }^{7}$ See, e.g., People v. Levin, 412 Ill. 11, 104 N.E.2d 814 (1952) (holding a penal provision in a Uniform Trust Receipts Act is not logically to be expected in a non-regulatory act); People v. Mahumed, 381 III. 81, 44 N.E.2d 911 (1942) (an "ordinary person of intelligence" would not conceive the presence of the penalty in the "heart-balm" act).

${ }^{8}$ E.g., Pickus v. Board of Education of the City of Chicago, 9 Ill.2d 599, 611, 138 N.E.2d 532, 539 (1956); Lasdon v. Hallihan, 377 Ill. 187, 196, 36 N.E.2d 227, 232 (1941). 
In construing the constitutional requirement of a singleness of subject, the tendency has been to adopt a liberal, rather than a strict, construction. To render a provision in the body of a statute void because it is not embraced in its title, the provision must be one which is incongruous or which has no proper connection with the title of the act. ${ }^{9}$

Although in Illinois, as in most other states, there is a presumption in favor of the validity of a statute, ${ }^{10}$ the subject-title provision is mandatory on the courts. ${ }^{11}$ In practice, however, there appears to be so much room for subjective "interpretation" that it is difficult, if not impossible, to predict with certainty the success with which a particular statute might be attacked.

Unity of Subject. If it can be successfully demonstrated that either the title or body of the act contains more than one subject, the consequences are fairly clear. Plurality of subject in the title alone is not fatal to the statute since the constitutional restriction only requires unity of subject in the body of the act. ${ }^{12}$ But if the body contains two subjects and only one is expressed in the title, the part not contained in the title is void. ${ }^{13}$ And where both the act and title embrace two subjects, the entire act must fall since the court, it is said, cannot elect one subject over the other. ${ }^{14}$ The result in the latter situation seems undesirable; if the title clearly indicates the contents of the act, it is unlikely that the mere presence of two subjects would mislead the legislature or the public. It would seem that this result could be avoided, as is done in some states, by ascertaining the major or "primary" subject.15

While the courts have long asserted various verbal formulae for determining the "subject" of an act, the recent tendency has been toward a more liberal

' E.g., People ex rel. Coutrakon v. Lohr, 9 Ill.2d 539, 549, 138 N.E.2d 471, 477 (1956); People ex rel. Brenza v. Gebbie, 5 Ill.2d 565, 126 N.E.2d 657 (1955).

${ }^{10}$ See, e.g., Campe v. Cermak, 330 Ill. 463, 161 N.E. 761 (1928) ("plain meaning"); Michaels v. Hill, 328 III. 11, 159 N.E. 278 (1927) ("Presumption of validity"); People v. McBride, 234 IIl. 146, 84 N.E. 865 (1908). Consult Sutherland, op. cit. supra, note 1, at $\$ 1706$. Compare Cloyd v. County of Vermillion, 360 Ill. 610,196 N.E. 802 (1935) ("Any reasonable meaning even if not common").

${ }^{11}$ See Galpin v. City of Chicago, 269 Ill. 27, 39, 109 N.E. 713, 718 (1915) (" " $[t]$ he court cannot permit such [constitutional] provisions to be . . . overridden in the enactment of legislation' "). A few states have taken the position that such provisions must be merely directory since otherwise most existing legislation would be void. Consult Sutherland, op. cit. supra, note 3 , at $\$ 1703$; Cooley, op. cit. supra, note 3 , at 311-2.

${ }^{12}$ People v. Solomon, 265 IIl. 28, 106 N.E. 458 (1914); People v. McBride, 234 Ill. 146, 84 N.E. 865 (1908).

${ }^{13}$ See cases cited note 14 infra.

16 E.g., Campe v. Cermak, 330 Ill. 463, 161 N.E. 761 (1928); Michaels v. Hill, 328 Ill. 11, 159 N.E. 278 (1927); Sutter v. People's Gas Light \& Coke Co., 284 Ill. 634, 120 N.E. 562 (1918).

${ }^{I 5}$ E.g., State v. Lancaster County, 17 Neb. 85, 22 N.W. 228 (1885); Reilly v. Knapp, 105 Kan. 565, 185 Pac. 47 (1919). 
finding of a single subject. ${ }^{16}$ The "subject" may be as broad and comprehensive as the legislature chooses and may include all matter "germane" thereto including the provisions reasonably necessary to accomplish the legislative purpose. Only unrelated or "discordant" provisions are prohibited. ${ }^{17}$ Concrete examples, however, will best illustrate the changing attitude of the courts.

In 1918, the Illinois Supreme Court held that the power of a municipality to sell surplus electricity was a "subject" separate from the power to regulate rates for electricity furnished by a public utility. Though both powers were related to the general power of a municipality, the former was deemed proprietory and the latter legislative. ${ }^{18}$ The power of a county to construct a county building was in 1928 held a subject separate from the power of the county to contract with a municipality for the location of such a building on municipallyowned property. The crucial difference was found in the fact that a county is an involuntary sub-division of the state while a municipality is a voluntary one. ${ }^{19}$

The modern decisions present a striking contrast. In Pickus v. Board of Education of City of Chicago, ${ }^{20}$ decided in 1956, the Illinois court held that an act entitled "An Act in relation to State Finance" could validly contain a provision withholding compensation from state employees who refused to sign nonCommunist loyalty oaths. Since the provision prescribes a condition precedent to the receipt of state funds, it was held to deal with that subject. The result in Pickus was justified by use of the second test described above. In 1955 the budgetary power of a sanitary district's Board of Trustees was considered to be inseparable from the subject of the power concerning appropriation and levy of taxes by the Board. Only the latter power was expressed in the title of the amending act. ${ }^{21}$ In a 1953 decision, the public acquisition of vacant lands for development of housing facilities, not limited to low rentals, was held to be

${ }^{16}$ E.g., People ex rel. Coutrakon v. Lohr, 9 Ill.2d 539, 138 N.E.2d 471 (1956); People ex rel. Brenza v. Gebbie, 5 Ill.2d 565, 587, 126 N.E.2d 657, 668 (1955) ("the tendency has been to adopt a liberal rather than a strict construction, to the end that the beneficial purpose for which the provision was adopted will not be defeated").

${ }^{17}$ E.g., authorities cited note 16, supra. See also, e.g., People v. City of Chicago, $414 \mathrm{Ill}$. 600,111 N.E.2d 626 (1953) (wherein the legislature's definition in the questioned act itself was determinative).

${ }^{18}$ Sutter v. People's Gas Light \& Coke Co., 284 IIl. 634, 120 N.E. 562 (1918).

${ }^{19}$ Campe v. Cermak, 330 Ill. 463, 161 N.E. 761 (1928). See also Michaels v. Hill, 328 Ill. 11, 159 N.E. 278 (1927) (holding the power of municipalities to incur debt a different subject from the executions and levy of county taxes).

${ }^{20} 9$ III. 2d 599, 138 N.E.2d 532 (1956).

${ }^{21}$ People ex rel. Brenza v. Gebbie, 5 Ill.2d 565, 126 N.E.2d 657 (1955) (act entitled "An Act to validate certain appropriation ordinances and certain tax levy ordinances heretofore adopted by the Board of Trustees of any sanitary district organized and existing under 'An Act to create sanitary districts to remove obstructions in the Des Plains and Illinois Rivers,' approved. . . ."). 
encompassed by the subject of slum clearance. ${ }^{22}$ The most striking aspect of these decisions is the heavy reliance by the courts upon the legislature's determination that the questioned powers were in reality single subjects. In the sanitary district case, the court relied upon the definition of "budget" in the original act as including appropriations and taxes. In the 1953 housing case the court was greatly influenced by the detailed statement, found in the questioned statute itself and in a similar federal housing act, of the required interrelation between vacant land and congested slum areas. While this liberal tendency is perhaps to be desired, the legislature's determination of what is "germane" should not be substituted for the court's own judgment of what may mislead a reasonable reader.

Scope of Title. Unity of subject alone is not sufficient to shelter a statute from an attack for non-compliance with the constitutional provision. ${ }^{23}$ The objectives underlying the unity-of-subject provision require as a corollary a proper relation between a statute and its title. ${ }^{24}$ While the title may be framed in general terms and need not be an index of the provisions of the statute, ${ }^{25}$ it cannot be so broad as to give no clue to its content. ${ }^{26}$ Perhaps the most helpful generalization is that the title must "fairly apprise the legislators and public in general of the subject matter of the legislation so as to reasonably lead to an inquiry into the body of the bill." ${ }^{227}$ The title is to be read through the eyes of "an ordinary person of intelligence." 28 It is the official title which the bill carried through both houses with which the courts are concerned. Deceptiveness of an editorial heading added by a publisher for the "convenience" of its customers cannot be blamed upon the legislature. ${ }^{29}$

The most frequently litigated question is whether the title of an act suff-

2 People v. City of Chicago, 414 Ml. 600, 111 N.E.2d 626 (1953) (new act entitled "An Act in relation to the eradication and redevelopment of slum and blighted areas and for the development and redevelopment of blighted vacant areas. . . "). Note the dissenting opinion at 624,640 wherein Chief Justice Crompton stated, "[e]xcept for appropriate redevelopment of sites formerly occupied by the cleared slums, a matter not involved here, the construction elsewhere of residences beyond the means of the persons displaced can have no appreciable effect in alleviating [the evils of congested slum areas]."

${ }^{23}$ See Heck v. Schupp, 394 Ill. 296, 299, 68 N.E.2d 464, 466 (1946), where the court indicates that "even though the purpose of the act be single, if that purpose is not expressed in the title, the act [provision?] is void."

${ }^{24}$ See, e.g., People v. Mahumed, 381 M1. 81, 44 N.E.2d 911 (1942); and cases cited note 5, supra.

${ }^{25}$ See, e.g., People v. City of Chicago, 414 MI. 600, 111 N.E.2d 626 (1953); People v. Kelley, 357 Hl. 408, 192 N.E. 372 (1934).

${ }^{20}$ Allardt v. People, 197 Ill. 501, 64 N.E. 536 (1902) (title held too general). See Rouse v. Thompson, 228 Ill. 522, 81 N.E. 1109 (1907).

${ }^{2 \pi}$ Heck v. Schupp, 394 Ill. 296, 299, 68 N.E.2d 464, 466 (1946).

${ }^{20}$ People v. Mahumed, 381 Ill. 81, 84, 44 N.E.2d 911, 912 (1942) ; Rouse v. Thompson, 228 IIl. 522, 81 N.E. 1109 (1907).

$\sim$ People v. Edge, 406 III. 490, 94 N.E.2d 359 (1950). 
ciently indicates the presence of a criminal penalty for its violation. Where the act by its title is "in relation to criminal jurisprudence," an attack on this ground is not likely to succeed. This phrase has been said to cover "all . . . imaginable offenses against the public law"; ${ }^{30}$ it has been held to include such diverse situations as the authorization of civil suits to recover penal damages, ${ }^{31}$ the prohibition of advocacy of violent overthrow of government, ${ }^{32}$ and the imposition of special penalties on habitual offenders. ${ }^{33}$

Even in statutes not purporting to create criminal offenses, criminal penalties are usually held to be sufficiently indicated by titles which state that the act shall "protect" or "regulate" a specific occupation or activity. This is the case, for example, with the "protection" of union labels" and bank depositors, ${ }^{35}$ and with the "regulation" of the admission of foreign corporations. ${ }^{36}$ Such statutes are considered "penal in nature" since no effective protection or regulation could be obtained without criminal sanctions. However, in Italia America Shipping Corp. v. Nelson, ${ }^{37}$ even though the title did not contain the words "protect" or "regulate," the penalty provision was uphelda "perusal" of the act showed its regulatory nature. A "reasonable" reader might expect such a provision if the title clearly indicated a regulatory act, but a requirement that one read the act to see if it is regulatory comes dangerously close to a denial of the need for any title at all. Of course, if the title clearly expresses the presence of a penalty, there is no attack open unless it be that of plurality of subject. ${ }^{38}$

Although it is often stated that no particular form or terms are required for a valid title, ${ }^{39}$ the use of such words as "concerning" or "in relation to" would not seem to indicate the presence of a criminal penalty. An exception might be made in such cases as Italia America Shipping, where the defendant, a banker, could more reasonably have been expected to understand the need for

\footnotetext{
${ }^{30}$ See Rouse v. Thompson, 228 III. 522, 533, 81 N.E. 1109, 1112 (1907). The court there continues, ". . . and also all proper provisions for the prevention of crimes, . . conviction, and punishment of all classes of offenders, and for fixing the jurisdiction ... of the various courts ... and prescribing the mode of procedure and the rules of evidence applicable to criminal trials."

${ }^{31}$ Larned v. Tiernan, 110 Ill. 173 (1884).

${ }^{32}$ People v. Lloyd, 304 III. 23, 136 N.E. 505 (1922).

${ }^{33}$ People v. Kukoch, 7 Ill. 2d 255, 130 N.E.2d 505 (1955) ; People v. Cohen, 366 Ill. 190, 8 N.E.2d 184 (1937).

${ }^{34}$ Cohn v. The People, 149 Ill. 486, 37 N.E. 60 (1894).

${ }^{35}$ People v. Colegrove, 354 Ill. 164, 187 N.E. 913 (1933).

${ }^{30}$ Guest Piano Co. v. Ricker, 274 Ill. 448, 113 N.E. 717 (1916).

${ }^{э} 323$ III. 427, 154 N.E. 198 (1926) (act "in relation to" dealing in foreign exchange).

${ }^{38}$ Stewart v. Brady, 300 Ill. 425, 133 N.E. 310 (1921) (title: An act relating to the sale of ... securities and providing penalties for the violation thereof ...).
}

${ }^{30}$ Heck v. Schupp, 394 Ill. 296, 68 N.E.2d 464 (1946). 
criminal sanctions; but even this is questionable since the degree of sophistication reasonably to be expected in each case is far from clear. Hence, a penalty provision could not be slipped into a uniform act "concerning" trust receipts which was considered merely to define and not to regulate the business usage of such instruments. ${ }^{40}$ Similarly, "an act in relation to certain causes or action conducive to extortion and blackmail ..." could not validly contain a penalty for identifying, without court approval, the co-respondent in suits for divorce of separate maintenance. ${ }^{41}$

Even where the title of an act specifically deals with criminal behavior, it has occasionally been held that if a new crime is created, this fact of newness must be expressed in the title. For example, in Milne v. People, ${ }^{42}$ it was held that an act "for the punishment of crimes against children" was invalid insofar as it created an entirely new crime. The court remarked, however, that if the title had included the words "to define and punish" it would have been sufficient. This "new crime" theory, however, is not successful where a defendant, such as a banker, may be expected to know the law. ${ }^{43}$ But an act relating to banks could not make it a misdemeanor for concerns which do not traditionally perform savings functions to deal in foreign exchange. ${ }^{44}$

Other statutory schemes are also susceptible to similar attack. For example, where the statute attempts to abolish a civil action ${ }^{45}$ or source of compensation for public officers, ${ }^{46}$ or to create a new civil action, ${ }^{47}$ the courts tend to scrutinize the title carefully. Also, a change of political territorial units requires clear notice to the inhabitants via the title. ${ }^{48}$

\footnotetext{
${ }^{10}$ People v. Levin, 412 Ill. 11, 104 N.E.2d 814 (1952) (Title: "An Act concerning trust receipts ... and to make uniform the laws relating thereto").

1 People v. Mahumed, 381 Ill. 81, 44 N.E.2d 911 (1942).

224 III. 125, 128, 79 N.E. 631, 632 (1906); In re Snyder, 108 Mich. 48, 65 N.W. 562 (1895) (similar child molester statute invalid).

${ }^{43}$ Italia American Shipping Corp. v. Nelson, 323 IIl. 427, 154 N.E. 198 (1926) ; People v. Colegrove, 354 III. 164, 187 N.E. 913 (1933).

"Wedesweiler v. Brundage, 297 Ill. 228, 130 N.E. 520 (1921).

${ }^{45}$ Heck v. Schupp, 394 IIl. 296, 68 N.E.2d 464 (1946) ("An Act in relation to certain causes of action conducive to extortion ..." could not abolish civil action for alienation of affection, breach of contract to marry, etc.); People ex rel. Clarke v. Jarecki, 363 Ill. 180, 1 N.E.2d 855 (1936) (Act "in relation to the payment of [delinquent real estate taxes]" held invalid because the title did not sufficiently indicate the waiver of accumulated interest, forfeitures and rentals).
}

${ }^{46}$ Galpin v. City of Chicago, 269 Ill. 27, 109 N.E. 713 (1915) ("An Act providing for the payment by the County of Cook of further compensation. . . " did not indicate that prior source was abolished).

${ }^{4}$ See Hollingsworth v. Chicago Coal Co., 243 Ml. 98, 90 N.E. 276 (1909).

ws Donnersberger v. Prendergast, 128 II. 229, 21 N.E. 1 (1889) (extension of boundaries of incorporated cities). 


\section{AMENDATORY STATUTES}

Statutes which amend or revise existing legislation, expressly or by implication, are subject to additional assault-both with respect to the subject-title requirement and the further provision of Section 13 of Article IV:

[N]o law shall be revived or amended by reference to its title only, but the law revived, or the section amended, shall be inserted at length in the new act.49

Historically this provision was designed to remedy the evil of "blind" legislation which resulted, sometimes intentionally, in confusion. The early acts often simply referred to the amended section and stated the words to be substituted or modified so that the amending act by itself would be meaningless. ${ }^{50}$ Hence, the underlying purpose of the requirement is to avoid the necessity of having to refer to the prior law to find the meaning of the amendatory act. ${ }^{51}$ Thus, it has been held that only the new section as amended need be printed. It is not necessary to reiterate in the new act the existing amended provisions of the old law still in force or to reprint all prior acts in any way modified by the new act. ${ }^{52}$ On the other hand where an existing section "is hereby amended by adding thereto section $\mathrm{X}$ to read as follows ..." the existing section affected as well as the new section X must be published. ${ }^{53}$ It would seem, however, that amendments consisting of single words or small phrases could readily be inserted in the newly amended section in such a way that the true import of the amendment might not be noticed. Printing the new material in some distinctive manner such as bold-face type or italics, would seem to be a desirable additional safeguard. ${ }^{54}$

Despite the seeming simplicity of the constitutional provision, there has been dispute concerning the determination of which statutes must comply with the provisions.

A confusing area-and hence a promising one for attacking statutes-is where the act does not expressly purport to amend any existing statute, but nevertheless has that effect. Where the new act is clearly complete in itself, no other act need be referred to on that particular aspect of the subject. The con-

${ }^{40}$ Consult note 1 , supra.

${ }^{50}$ See Lombardo Wine Co. v. Taylor, 407 Ill. 454, 95 N.E.2d 607 (1950) ; People v. Knoff, 183 IIl. 410, 56 N.E. 155 (1900). I Cooley, op. cit. supra, note 3 at 314.

${ }^{5}$ See Co-ordinated Transport v. Barrett, 412 Ill. 321, 106 N.E.2d 510 (1952); People v. City of Peoria, 374 Ill. 313, 29 N.E.2d 539 (1940).

${ }^{52}$ E.g., People v. Gaylord BIdg. Corp., 369 Ill. 371, 16 N.E.2d 901 (1938); Crocher v. Abel, 348 Ill. 269, 180 N.E. 852 (1932) ; Cooley, op. cit. supra, note 3.

${ }^{63}$ E.g., Galpin v. City of Chicago, 269 Ill. 27, 109 N.E. 713 (1915) (changing source of compensation of state's attorney from fines to salary) ; Lyons v. Police Pension Board, 255 IIl. 139, 99 N.E. 337 (1912).

I I Sutherland, Statutory Construction 347 (3d ed., 1943). 
stitutional provision is therefore inapplicable even though existing legislation may be amended by implication. ${ }^{55}$ The undesirability of republishing all affected legislation is patent. ${ }^{56}$

Whether a statute is "complete in itself" depends upon the substance of the act rather than the form of its title. If, upon a comparison between the questioned act and existing statutes, it appears that the new law has merely "intermingled" new provisions with the old so that both acts must be consulted to determine the law on that "branch" of the subject matter, the act must fall. ${ }^{57}$

It is also not unlikely that the courts' attitude toward the substantive policy of an "original" act may influence its judgment. For example, a police pensions act was held not "complete in itself" since it failed to require actual services or provide for non-active duty. ${ }^{58}$ Similarly, in two recent liquor-control cases the acts in question were struck down as improper attempts at indirect amendment inasmuch as they contained no provisions for procedural safeguards in the liquor commission hearings. ${ }^{59}$

A contrast is provided by the recent decision in the Pickus case upholding a non-Communist loyalty affidavit provision in an act "in relation to state finance." 00 The court rejected the argument that this was an incomplete amendment of statutes relating to civil service employment and school teachers' tenure, and was therefore void for failure to reprint the amended acts. The court deemed the provisions complete in themselves and went on to state that the constitutional provision applies only when the law is expressly amendatory or clearly so by its exhaustiveness. This position is now taken in many states. ${ }^{61}$

Limiting the republication provision to expressly amendatory statutes, however, would appear to lead to an anomalous result. By intentional failure to

${ }^{55}$ E.g., Starck v. Chicago \& Northwestern R. Co., 4 Ill. 2d 616, 123 N.E.2d 826 (1954) (act "in relation to Municipal Courts ..." was complete as to selection of juries despite jury commissioner's Act); People ex rel. Gutknecht v. Chicago Regional Port District, 4 Ill.2d 363, 123 N.E.2d 92 (1954) (an act "To create a [Chicago Reg. Port. Dist.] . . and to define its duties" complete and valid despite incidental amendment).

${ }^{50}$ See Timm v. Harrison, 109 Hll. 593 (1884); and the famous case of People v. Mahaney, 13 Mich. 481 (1865).

${ }^{57}$ DeMotte v. DeMotte, 364 IIl. 421, 4 N.E.2d 960 (1936) (separate maintenance statute could not modify desertion as ground for divorce); Chicago Motor Club v. Kinney, 329 III. 120, 160 N.E. 163 (1928) (use of "road" funds); Board of Education v. Haworth, 274 Ill. 538, 113 N.E. 939 (1916) (use of state school funds).

${ }^{88}$ E.g., Wagner v. Retirement Board, 370 Ill. 73, 17 N.E.2d 972 (1938); see Demotte v. Demotte, 364 Ill. 421,4 N.E.2d 960 (1936).

${ }^{t}$ Lombardo Wine Co. v. Taylor, 407 Ill. 454, 95 N.E.2d 607 (1950) (Price Posting Act held improper attempt to extend powers of Illinois Liquor Control Commission); Illinois Liquor Commission v. Chicago's Last Liquor Store, 403 III. 578, 88 N.E.2d 15 (1949) (Mandatory Fair Trade Act held similarly an improper amendment of Liquor Control Act).

${ }^{\infty}$ Consult text discussion at p. 725, supra.

${ }^{61}$ I Sutherland, Statutory Construction $\$ 1917$ (3d ed., Horack, 1942); cases cited in 5 A.L.R.2d 1270 (1949). 
warn the reader of the amendatory nature of an act, the legislature could safely disregard the constitutional safeguard and rely upon the "completeness" of the specific provision in question. As evidenced by the Pickus case, this would throw the entire burden of protection upon the subject-title provision which is currently being undermined by liberal "interpretation." 22 It has been suggested, on the other hand, that this position should be adopted generally. ${ }^{63}$ The increased use of revised statutes, up to date private compilations and annotated statutes, as well as the declining possibility of "blind" amendment, facilitate intelligent interpretation of statutes and reduce the justification for the constitutional requirement of republication.

It is possible validly to incorporate a provision of one act into another by an unambiguous reference to the adopted provision. Where one act clearly refers to a specific provision of another it is held that the provision so incorporated by reference has been validly written into the adopting act even though both acts must be examined. ${ }^{64}$ But the reference must be unambiguous. ${ }^{65}$ For example, reference to another act for a definition where the adopted section does not contain the term to be defined is invalid to the extent that the adopting act is ambiguous. ${ }^{66}$

It is often stated that where the title of an expressly amendatory act repeats the title of the amended statute, any additional provision which might validly have been inserted in the latter may be included in the amending statute. ${ }^{67}$ In attempting to increase the scope of existing acts, however, amendatory statutes are likely fatally to include more than one subject in the body and title. ${ }^{68}$ But as has been observed in cases involving local tax authority ${ }^{09}$ and slum clearance cases, ${ }^{70}$ the modern tendency is for the court to be

20 Consult text discussion at pp. 725-26, supra.

I I Sutherland, op. cit. supra note 3 at $\$ 1918$.

6. E.g., People v. Lewis, 5 Ill.2d 117, 125 N.E.2d 87 (1955) (act revising interest penalty payable on redemption validly incorporated procedure by words "shall be computed in the same manner as is provided in $\$ 253 ")$. See People v. City of Chicago, 3 Ill.2d 539, 121 N.E.2d 791 (1954).

${ }^{65}$ E.g., People v. Thompson, 381 Ill. 48, 44 N.E.2d 899 (1942) ("in like manner and with like notice as in County Election" held not sufficiently precise reference).

${ }^{\text {es }}$ People ex rel. Schoon v. Carpentier, 2 Ml.2d 468, 118 N.E.2d 315 (1954) (definition of "use" not found in adopted section).

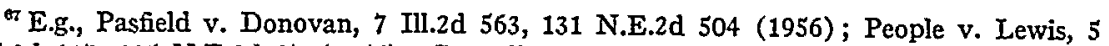
Ill.2d 117, 125 N.E.2d 87 (1955); Co-ordinated Transport v. Barrett, 412 Ill. 321, 106 N.E.2d 510 (1952) ; City of Evanston v. Wazau, 364 Ill. 198, 4 N.E.2d 79 (1936).

${ }^{*}$ E.g., Michaels v. Hill, 328 Ill. 11, 159 N.E. 278 (1927) (Amendatory Act could not expand act concerning county taxes to include municipal debt provisions). Compare Donnensberger v. Prendergast, 128 Ill. 229, 21 N.E. 1 (1889) (Township Act could not include incorporated villages).

${ }^{\infty}$ People ex rel. Brenza v, Gebbie, 5 Ill.2d 565, 126 N.E.2d 657 (1955).

${ }^{70}$ People v. City of Chicago, 414 M1. 600, 111 N.E.2d 626 (1953). 
more inclined to find only a single subject. And, of course, the scope of the amended act could be increased by suitably amending the title. ${ }^{71}$

Subject-title doctrines have been used in several recent decisions to eliminate, at least partially, the need for even expressly amendatory acts to comply with the constitutional republishing requirement. Where the title of an expressly amendatory act purports to amend only specific sections of the amended act, but in fact changes additional sections thereof, the unannounced amendment has been upheld on two interrelated grounds. It is reasoned first that since the title of the old act is fully repeated, anything germane to the amended act may be included in the new amending act. Secondly, those changes not identified by the title of the new act are upheld despite noncompliance with the reprinting provision if they are "complete in themselves." Thus, an expressly amendatory statute is treated in part as if it were amendatory by implication only. Since one must read the old act to determine whether this has been done, the efficacy of even expressly amendatory titles is greatly reduced. ${ }^{72}$

A final comment upon the problem of general revisions or codifications should be made. A general revision or codification is generally said to repeal by implication all provisions of existing acts on the same subject which are umitted from the revision or compilation, even though there is no repugnance or express repealing clause. ${ }^{73}$ A true "revision," then, is not an "amendment" to which the constitution applies. ${ }^{74}$ This result, however, depends upon evidence of a legislative intent to cover the whole subject and to frame a new legislative "scheme." Such an intent is clear, for example, where both the old act and the new revision are identically headed or where the new act exhaustively covers the subject. ${ }^{75}$ But the label of "revision or codification" will not protect an attempt to revive a previously repealed act. ${ }^{76}$

\footnotetext{
${ }^{7}$ See ibid.; Department of Pub. Wks., etc. v. Chicago T. \& T. Co., 408 Ill. 41, 95 N.E.2d 903 (1950) (increasing scope of department authority over state parks).
}

${ }^{72}$ E.g., Sangamon County Fair, etc. v. Standard, 9 Ill.2d 267, 137 N.E.2d 487 (1956); People ex rel. Bentson v. Bowen, 9 Ill.2d 69, 136 N.E.2d 806 (1956); Co-ordinated Transport v. Barrett, 412 III. 321, 106 N.E.2d 510 (1952); Clarke v. Storchak, 384 Ill. 564, 52 N.E.2d 229 (1944).

${ }^{73}$ See, e.g., People v. Horwitz, 362 Ml. 289, 199 N.E. 788 (1936) (General Assembly was in the act of revising all the criminal laws); People v. Borgeson, 335 IIl. 136, 166 N.E. 451 (1929) (both old and new acts entitled "Deadly Weapons" showed legislative intent to repeal old acts).

"This is also true in about nineteen other states which have similar prohibitions against amendment by reference to title only. I Sutherland, op. cit. supra note 3.

${ }^{75}$ For example where public utilities were completely regulated as in Illinois Central $\mathbf{R}$. Co. v. Illinois Commerce Com'n., 397 Ill. 387, 74 N.E.2d 526 (1947); Northern Trust v. Chicago Rys. Co., 318 IIl. 402, 149 N.E. 422 (1925); or comprehensive legislation concerning the administration of estates and probate of wills as in Brooking v. Brooking, 391 Ill. 440, 63 N.E.2d 476 (1945).

${ }^{78}$ City of Chicago v. Iovino, 400 III. 354, 81 N.E.2d 171 (1948) (a repealed ordinance could not validly be re-enacted merely by reprinting in official revision and compilation). 
In sum, it appears that the Illinois Supreme Court has adopted a liberal attitude in applying the subject-title and amendatory requirements of the constitution. Little, if anything, seems to be left of the requirement that amended provisions must be reprinted at length in the amending act even where the new act is expressly amendatory. The impossibility of reprinting all acts in any way affected by the new legislation, and increased use of convenient annotated compilations have led the Court to inquire whether the questioned provision is sufficiently "complete in itself" that no other act need be consulted to determine the law on that part of the subject. It is here that an attack upon a statute expressly or impliedly amendatory is most likely to succeed. ${ }^{.7}$ Thus, the declining effectiveness of the amendment provision has placed the burden of procedural safeguard upon the subject-title requirement.

$\pi$ By way of anticipation, one might speculate upon section 770 of the new Illinois Savings and Loan Act. Ill. Rev. Stat. (1955) c. 32, \$770.

This act is titled "An Act to revise and codify the laws in relation to Savings and Loan Associations and to provide penalties for the violation thereof and to repeal an Act therein named." Section 770 deals with joint accounts, trust accounts, and payment-on-death accounts. It contains for the first time provisions which might well be construed to "amend" the Probate Act insofar as it purports to allow a testamentary disposition of the account funds without complying with the formalities required for the execution of wills. Consult, for example, the discussion to that effect in Bank Accounts: Transfer of Property at Death, 23 U. of Chi. L. Rev. 289, 296-97, 301-8 (1956).

Assuming that the provision is so construed, what is the likelihood of successful attack on Art. IV, $\$ 13$ grounds? Briefly the provision could be upheld on the following grounds: 1) The act is a clear attempt at general revision and codification and as such is not subject to "amendatory" prohibitions; 2) The act is complete in itself-there is no need to refer to the Probate Act with respect to testamentary dispositions of such trust accounts; and 3) The act relates to the single general subject of Savings and Loan Associations to which the effects on their trusts accounts is "germane." On the other hand, it can be argued against the provision that: The provision creates an ambiguity with respect to testamentary dispositions which may have been unexpected and unintended by the parties despite the signing of a signature card agreement. See Estate of Schneider, 6 Ill.2d 180, 127 N.E.2d 445 (1955), and consult 23 U. of Chi. L. Rev. 289 (1956). Furthermore this is an extraordinary departure from established custom and usage which should have been indicated in the title. The policies with respect to the probate of wills and administration of estates designed to protect creditors of the estate are firmly established.

\section{THE UNION RIGHT TO REQUIRE EMPLOYER MEMBERSHIP}

A recurrent problem of labor law has been the legality of union attempts to extend control over employers beyond the traditional sphere of wages, working conditions and employee membership. The Barbers Union ${ }^{1}$ attempted such an extension of control by three successive amendments ${ }^{2}$ to its constitution requir-

\footnotetext{
${ }^{1}$ The full title of the union is Journeymen Barbers, Hairdressers, Cosmetologists and Proprietors International Union of America, A.F. of L. Prior to the amendments requiring employer membership, the union went under the title of Journeymen Barbers, Hairdressers, and Cosmetologists' International Union of America.

${ }^{2}$ The first amendment provided that the employer must be a nonactive member who was not entitled to vote or to a seat in union meetings or to hold any office or to serve
} 